\title{
OPPOSING VIEWS IN WEBBER'S JESUS CHRIST SUPERSTAR: A DECONSTRUCTION ANALYSIS
}

\author{
Oktavianus Dengah, Mister G. Maru, and Imelda Lolowang \\ ${ }^{I}$ Englih Education Department, Faculty of language and arts, Universitas Negeri Manado \\ otadengah@gmail.com
}

\begin{abstract}
Opposing Views in Webber's "Jesus Christ Superstar" is the focus of the analysis in thisskripsi.The approach is applied to analyze the data since the data is needed the primary source. "Jesus Christ Superstar by Andrew Webber Opposing views in the drama can be observed through all the characteristics of Judas Iscariot. In this drama, there are some things that are contrary for Christian because some scenes are not the same as the real story. As a result of Judas's view that made Jesus's role different, giving rise to contradictory things, Judas was one of the followers who disliked the personality of Jesus, so there was no existence of Jesus to heal, a sense of compassion, and other powers that looked ordinary. Writers use deconstruction analysis to find out the opposition the drama. Through this skripsi, the writers can find things that are contrary to Christian faith and can also be used as a moral message in everyday life, whether in religious life, moral messages for teachers, and what can be taught things that can be used as moral values to students in school as character education.
\end{abstract}

Keywords: Opposing views, Deconstruction, Jesus Christ, and. Judas Iscariot.

\section{INTRODUCTION}

The literary work is a result of human thought. Appropriate to what we have seen and felt thereby creating a more interesting work. With Literature, people can reach their expectation and desires. According toWuntu CN. (2015):

"A literary work which has affective nature is a significant power of touch the deepest sense that can produce perfect consciousness as it successfully carries out its mission as a form generator of human consciousness." (100)

It can be concluded that literary works can touch human feeling that can produce a response that is perfect consciousness. After some people read the literary work, then they can respond and can understand and appreciate literary works. Literature can be said to be successful because literature carries out its mission as a generator of human consciousness.

For this research, the author choose drama musical Jesus Christ Superstar. That is a literary work that does not use dialogue, but each song has meaning work therein. This drama almost same with the story about Jesus but this is different from the story before, because this is not take from bible narratives. In accordance stories created by the authors, Judas Iscariot is one of the more prominent figures, evident from the beginning until the end of the story is seen that Judas is a preferred character. Judas is one of Jesus' followers. But as long as $\mathrm{He}$ became followers, Judas entered by evil spirits. He saw all that Jesus did was bad. And that's when Judas betrayed Jesus. As a 
result of treachery, Judas sold Jesus to Caiaphas, the judgment under Pontius Pilate in the flogging and crucifixion.

The writers interest to choose this drama musical because this is challenge thinking, trust or ideas have been grasp or known to some Christians. This work is also unique because it is form of drama or musical opera with rock genre included song lyric that are packed with interesting and creative.

\section{RESEARCH METHODOLOGY}

In this research, the writers use qualitative research. According to Bogdan and Biklen (1982:27): "Qualitative research has the natural setting as direct source data and the researchers are the key instrument in addition, mechanically recorder materials are viewed in their entirely by the researchers insight being the key instrument for analysis. Based on this opinion, the writers take some data from book source that have related with the topic, and the writers make in qualitative research. Literary work here becomes objective of the study.For data colection, the writers use two kinds of sources. Those are primary source and secondary source.

Drama musical "Jesus Christ Superstar" is the primary source of this research and the other references which have relation with the story to support the writers to complete the data is secondary source. The writers add the theological book and several articles as the secondary resources for this research.

As the method analysis, writers use deconstruction analysis. From this method, it will help writers to find out the things from drama. Griffith (2011) argued that:

"Deconstruction is a theory of language, developed by Jacques Derrida and based on the linguistics of Ferdinand de Saussure, that rejects certainty of meaning in linguistic communications, including especially literature. To "deconstruct" a work of literature is to expose its contradictory ideas and thus its lack of meaning. (246)

Thus, it can be concluded that deconstruction literary criticism can subvert the opposition between two ideas, which are the contents of an important arrangement. Author can get anything that opposition between two opposing ideas. Deconstruction can make it easy for writers to analyze the drama "Jesus Christ Superstar" through Jude Iscariot. And also, the writers can find any facts that oppose Christianity by examining the whole drama compared with what theauthors expect.

\section{DATA ANALYSIS}

The writerswould deconstruct anything in the drama of "Jesus Christ Superstar" in Christian life with seeing the side of Judas Iscariot's view of Jesus. The story would be different from the story of Jesus before. This story told the life of Jesus starting with his story in Jerusalem until he was crucified and died. However, this drama told in the view of Judas. Through the character of Judas, the writer could find any things that differ in view in every approaching drama scene. According to Balkin (1987) claims that:

"For Derrida, any hierarchal statements about a set of ideas A and $B$ is an invitation for deconstructive reversal-to show that the property we ascribe to $A$ is true of $B$ and the property we ascribe to $B$ is true of $A$. Our deconstruction will show that $A$ 's privileged status is an illusion. 
For A depends upon B as Much as B depends upon $A$. We will discover, then, that $B$ stands in relation to $A$ much like we thought $A$ stood in relation to $B$. (6)

It can be concluded that by deconstruction the writers could determine a set of ideas between $A$ and $B$. The writerscould explain these two ideas with two opposing sides, and also, can determine which is more appropriate to be privileged. Through that the writers would divide several parts to deconstruct the Drama "Jesus Christ Superstar". There are three parts to the chapter that the writers will discuss, the first the writers would discuss the heavenly view versus the earthly, the second about powerful versus ordinary, and the third holy versus unholy. These three sub-sections will be discussed below. The reason the writers use this three opposite sub-chapters is because these three subchapters are parts of existing characters and that will be discussed in this analysis.

\subsection{The Powerful versus the Ordinary}

Powerful is relating to strength or energy. Powerful means that having a lot of power to control people and events. It can be interpreted, namely something that has the power and energy that can do everything so that it can be fulfilled as needed. Powerful is the character of Jesus Christ. He who has a power can change everything is according to the Christian faith. God has a real power. He is able to do everything with His mighty power as the creator of the universe and has the power to heal those who are obedient and loyal to him. Power means that His power is not possessed by anyone. According to B. J. Boland (2000) stated that:
"God has revealed himself to be an almighty Father, when He raised Jesus Christ from the dead......" (22)

This is a part of Christians that they believe where God is powerful and has a power to raised Jesus Christ from the dead. Only Godis able to do all things through His power.With His power, God can change everything with save those who love Him and able to keep believers in their daily life. According to Verkuyl (2001) stated that:

".....God is allpowerful. His power can do what is intended by His love. He is the only ruler and full of happiness. King of kings (1 Tim. 6:15), existing and future." (Rev.1: 8).

God is the King of kings As King through His love. The King does everything is according to what $\mathrm{He}$ intended. That is because he is skilled; there is no way he can do everything without Love. Therefore, he does his power since the Lord of the world is brought to the world someday.According to Soedarmo(2015) arguedthat :

"Only He, who is truly a true human being perfectly from the true God, is the only one who can withstand God's justice and can free man from God's punishment." (109)

The expression shows that Jesus has power, where he is truly a righteous and perfect. He can hold back the justice of God and free believers from God's law. This means that God shows His power so that humanity who believes in the law by God.

And this becomes an opposition of the powerful that be possessed by the character of Jesus Christ namely Ordinary.Ordinary is no special or distinctive features or normal. So ordinary can be interpreted as nothing special and can 
be called something that just normal and that is in the character of Judas who has the view is only mediocre and nothing is specified in the character of Jesus Christ as Powerful. The author gets one quote, which is ordinary said by Judas.

JUDAS. They think they've found the new MessiahAnd they'll hurt you when they find they're wrong.(1.1.18)

Judas criticizes believers who he said that His followers finding a messiah. If they find something wrong, Jesus will be hurt by His followers. Judas's mind becomes negative when sees the absences of power in Jesus as messiah. There is one scene that is different from the general story where Jesus Christ came somewhere and was visited by many people and asked for healing in Jesus Christ but Jesus could not heal the people who asked him for it like the drama of the phrase below:

JESUS. There's too many of you, don't push me. It's too little of me, don't crowd meHeal yourselves!(1.11.32-34)

This expression is a different and ordinary one, because it is not generally included. Jesus is no notable to healing people who are sick. With his emotions, he says that those who are many must heal themselves. It can be concluded a little that the power God is not seen here and ordinary. One of the scenes below is where Judas plans to sell Jesus to Caiaphas. When below is a song where Judas reveals about Jesus.

JUDAS. I came because I had to be the one who sawJesus can't control it like he did beforeAnd furthermore, I know that Jesus thinks so tooJesus Wouldn't mind that I was here with you.(1.14.9-16)
This expression also has a thing where Judas says Jesus cannot control himself. It shows that in Jesus he cannot control himself. From the point of view of Judas, Jesus Christ becomes ordinary; Jesus has no power over compared to Powerful, which Jesus actually possessed.

\subsection{The Holy versus the Unholy}

Holy is not mixed with elements that affect others. Describe something as holy, itmeans that it is special because it is only in God and is far apart from Man. That is God is in the character of Jesus Christ.God is holy. His holiness makes Himself different from humans because God is in a separate place, far from humans, and is not as capable as humans. God is sinless, he does not do things that are not deviant not like those who sinned who lost their holiness.According to Verkuyl (2001) stated that:

"The Bible claims that God is holy. This notice of God's holiness is emphasized thus, until the old covenant, for example, is often called the book of holiness. " (37)

God's holiness has existed since the existence of the scriptures. About holiness becomes a very emphasized in the scriptures. There is no denying the holiness of God. Just as it has been said that in the old conventions it is often mentioned the holiness ceremony.

God also wants to make believers to be holy as He is holy. Through His creation, God wants believer to enter into a love relationship with Him. So, if believers love God or have a loving relationship with God, then God will make believers Holy.God loves human, He humbles himself and $\mathrm{He}$ gave His life for us. Apart from being holy, through His love for believers, He humbled Himself to come into the world, ashuman; 
even He gave His life for those who believe in Him. According toVerkuyl (2001):

"We will know this justice of God, if we can experience, that we can experience, that he keeps his promise and that we can, trust everything in Him in our lives and death. God is faithful and just." (psalm 116,140,122), (39).

God shows His loyalty and justice to all believers for or believers to experience Him. God will occupy His promise so that believers will remain loyal to Him. Believers believe that $\mathrm{He}$ will never leave them because $\mathrm{He}$ is always faithful and fair. That is why Jesus is Holy.

In the drama, Judas Iscariot revealed as if God was not Holy anymore. Which eventually became a challenge to what was believed so far. This is the first scene of Judas with his unholy character.

JUDAS. My mind is clearer now At last all too well

I can see where we all soon will beIf strip away the myth from the man you will see

where we all soon will be (1.1.1-16)

That is very clear that Judas Iscariot did not like what he saw about Jesus. That is a negative expression for Jesus who directed Jesus to be considered low and did not show his holiness. Judas underestimated the presence of Jesus as a challenge for believers today. And this is truly evident in the presence of unholy in Judas Iscariot, then through the phrase singing from Mary Magdalene. In Judas's view. Mary Magdalene did something that was unholy and so that her view became unholy. Like the expressions below:

MARY MADGALENE. Let me try to cool down your face a bit.

JESUS. That feels nice, so nice

\section{$(1.2 .17-24)$}

Judas saw the relationships between Mary and Jesus. At that time Mary came to Jesus and gave her peace. Jesus was pleased with the presence of Mary Magdalene. Through the view of Judas, this action is a deviation for him or also called unholy.Jesus then rebuked Judas for his dislike of Judas who received service from Mary but not according to expectations. Because,Jesus just denigrates Judas which is revealed below.

JUDAS. It seems to me a strange thing, mystifyingthat a man like you can waste his timeon women of her kind(1.3.1-9)

JESUS. Who are you to criticize her? Who are you to despise her?Leaver her, leave her, let her be now.(1.4.10-21)

In the end, the phrase arose one thing whichis challenged when Jesus rebuked Judas. Jesus was not supposed to say that because he had bullied Judas. As believers, it is impossible to believe in the words of Jesus. But that is why if this drama is more telling Judas itself. And from Judas's view of Jesus became unholy. In the next scene, at night before Jesus slept, Mary took care of Jesus and looked after him until Jesus slept After that Mary sang a song that showed her love for Jesus.

MARY MAGDALENE. Sleep and I is soothe you, calm and anoint youMyrrh for your hot fore-head oh the you'll feel. tonight.(1.13.1-9)

Through this scene, Mary loves Jesus very much. But it is very clear that Mary is very eager to have Jesus as her lover. According to Judas's view, they have special or more special relationships. This is not in accordance with the character of Jesus 
Himself and this opposed than the story generally. And it is said that there is a conflict between holy and unholy. The next scene is Jesus' expression to Judas in the scene entitled "The Last Supper".

JESUS. You are wild - you Judas
JUDAS.You want me to do it!
What if I just stayed here
And ruined your ambition?
Christ you deserve it!
JUDAS. Hurry you fool, hurry and
go,save me your speeches, I don't
want to know - Go!(2.1.20-40)

The above quote shows that Jesus said a harsh word to Judas. Jesus was very angry with Judas because of his disloyalty and often his behavior was evil. But this expression of Jesus does not indicate his sainthood as a person who is admired who can be judged to be an act that does not reflect of love. Next unholy expression in the scene titled "Superstar."The story is indeed Judas committed suicide. But Judas is still in the second last scene and criticizes about Jesus.

Judas Iscariot criticizes the existence of Jesus Christ and wants to know more and ask for answers from him. Because Judas does not understand what the truth is in the character of Jesus. Judas Ask what you sacrificed to him.But according to the drama, Jesus Christ just kept quiet as if there was no holiness in him and did not act according to his will. Judas glittered like a superstar and when he sang he asked Jesus according to the phrase above. It shows that the material of ridicule against Jesus who is not holy is through Judas Iscariot's view.

\subsection{The Heavenly versus the Earthly}

Heavenly is a thought or view that is related to Heaven and God. That is one of the characters of Jesus. Heavenly thought means that Jesus has a character that be recognized by His followers and still has a connection with the kingdom of heaven or can be called divine.

In Christian life, it is acknowledged that, in God, heavenly has various characters whom show themselves that $\mathrm{He}$ is a saviour to his followers, where can I raise His followers to live with Him in Heaven.Verkuyl in Intisari Iman Kristen (2001) argued that:

"God is love; that means, he will not give us a little, not too much but all, he gives us everything, so that we are helped from the clutches of sin to obtain salvation and to be led back to our original purpose for as long as This is not a conjecture. This is a reality in Jesus Christ. Jesus Christ is the revelation of God's love. "(39)

That impossible if God cannot allow believers not in the way of truth or the way of salvation. He showed His love through His miraculous work. God helps sinful people to obtaining salvation for free and returns to His righteous and righteous path. This is the character of God in Jesus that makes people believe and follow all rules or God's Law, one of them and foremost is Love. That is heavenly owned by Jesus Christ.Quotation from Verkuyl (2001) argued that:

"The reality of the revelation of God as the creator are an important mandate." Revelation of Christ ", namely the revelation of God, as the redeemer and Savior, is also related to the revelation of God as creator. The Word, which has become human in Jesus Christ, is the word 
that has made the world. "John 1: 3. (10)

The quotation above is a proof that heavenly in Jesus is the one who saves believers, and that is not a taboo thing, because Jesus Christ is a commandment that has become a human being as well as commandment that has created heaven and earth and all its contents. Jesus Christ will redeem sinners and save. Jesus Christ is one of the many followers. Even they admit that they will be saved. Like this drama in a song titled Simon Zealotes"

CROWD. Christ you know I love
you
Did you see I waved?
I believe you and God
So tell me that I am saved.
Christ you know I love you
Did you see I am wave?
I believe in you and God
So tell me that I saved
Jesus I am with you
Touch me touchme Jesus
Jesus I am on your side
Kiss me kiss me Jesus.
(1.8.1-12)

The song is revealed by Simon and his followers showed that they love Jesus Christ who has heavenly, they cheered with joy and show their trust in Him. They say that they will be saved by Him. This is the proof and the positive side of this drama. Where in this drama is an expression where they will have a time to be saved.

And this is what is heavenly opponent, earthly. Earthly means relating to humankind material existence from a spiritual or heavenly one. So earthly, that is worldly thought that are not according to the will of God. One is evil, sinful, or also an act that does not chill by God.
Earthly is in Judas himself who has a view that contradicts Jesus. The following is the expression of Judas who acknowledges that Jesus' teachings are very excessive, such as his song entitled "Heaven on their minds"

$$
\begin{aligned}
& \text { JUDAS.All your followers are } \\
& \text { blind,Too much heaven on their } \\
& \text { minds.It was so beautiful but now } \\
& \text { it's far.(1.1.31-32) }
\end{aligned}
$$

What is revealed by Judas has a hidden meaning in which he criticized the actions of Jesus who fooled his followers with the heavenly teachings he taught. His followers were considered blind and received too many teachings given by Jesus. Indeed, the teachings of Jesus Christ were very beautiful, but now Judas feels that there is something far from his teachings. It shows that God is not a savior by Judas's view. And this is an earthly thought in Judas.

Humans believe that God is fair, He who has heavenly nature does everything and acts justly so that believers will always be obedient and loyal to Him. According to Soedarmo (2015) claims that:

"God's justice has a positive angle, which is rewarding those who obey Him and a negative angle, is to impose punishment on the wrong person." (108)

It can be concluded that in His justice, He rewards those who obey His law so if believers obey Him then He will justly give blessing to those who need God's power. But instead God will punish those who sin to Him. There it addresses God's heavenly justice for believers. Different views held by Judas. Judas 
precisely criticizes Mary Magdalene's actions to Jesus, which is actually a deed or can also be heavenly like what Judas said below.

JUDAS. Woman your fine ointment brand-new and expensive can have been savedfor the Poor__ Why has it been wasted? We could have raised maybe 100 silver pieces or more__People who are hungry, people who are starving, matter more than your_ feet and hair.(1.5.12-16)

The expression above through the earthly view of Judas shows that Jesus took an unfair action against those who were starving compared to His feet and hair which was oil by Mary Magdalene for Oil which was worth more than three hundred silver pieces. It was wasteful for Judas because it was not only a new product, but also expensive. Judas also said why it was not given to those who were more intoxicating, namely the poor. Before the author explained that God is just but here shows that God is unjust. That is against the heavenly justice of God. This is just like the responses of an atheist.Friedrich $\mathbf{N}$ in Baharudin (2012) Claims that:

".....Now God is dead and buried, therefore humans need not fear sin anymore. He is free to determine his fate and become a superhuman....."(108-109)

God seems to have ceased to exist. God is dead and can't do anything. God automatically cannot save believers and act fairly. This is a false expression and includes contrary to the Christian faith. Judas thought like that, he criticized as if
God was absent, and he was a superhuman. This is the same and becomes an earthly view from Judas.

Thus, it can be concluded that there are true contradictions in the drama "Jesus Christ Superstars". Despite the challenges, the drama can be taken on the positive side where there are several scenes that are the same as the story before. However, the writers prefers things that are related to the divine nature that Jesus possesses himself, compared to the drama "Jesus Christ Superstar" which, told according to Judas' Judgment. Because, that is more positive than some parts of the story.

\section{CONCLUSION}

Through this drama, it can be concluded that the existence of conflict according to the Judas view does not address the power, sanctity, and strength in Jesus. This drama does not match the writers'expectations, which should be in accordance with the teachings believed by Christians. Judas did not show the true personality of Jesus through this drama. Finally, with deconstruction analysis writer found the opposing views in the drama "Jesus Christ Superstar" through the view from Judas.

The moral message that can be taken from the drama is do not let us think negatively with people around the same as Judas who always thinks of evil things about Jesus. Then we have to think positively so that something does not happen. In religion, we should not be influenced by things that are misleading. But the good side can be taken that this drama is a story that we must believe that this drama is a version and according from Judas. Through EFL lessons at school, Teachers and students can also take moral messages that can be applied in 
their lives included teachers who give a motivation to students. According toNihta N. F. Liando (2012) argued that:

“..... (2) Institutions also play an important role in making the students successful therefore schools and its components including teachers must be improved, (3) students themselves must be given motivation because they are the ones who would have benefits in learning. (47)"

This is very Important for School institution including teachers to play an active role in providing motivation to student. In giving a lesson, teachers can provide motivation so that they are motivated to achieve success. Teachers and students must establish good relationships by communicating well, always understanding, before teaching give provide motivation and enthusiasm to students, students also comply according to advised by the teacher. To establish relationships between teachers and students. And also, they can provide examples of the surrounding community. Because through the character of Judas, he did not want to build a good relationship with Jesus, so that even contradictory things happened.

(As a writer suggested that this research could be a contribution in the Department of English Language faculty of language and art of Manado state university. Especially in the study of literature. Presumably can encourage students to be interested in analyzing literary works. And the researchers can also carry out more research through the literary work under study.)

\section{REFERENCES}

Abrams, M.H. "The Mirror and the Lamp"
: Romantic Theory and the Criical Tradition. USA : Oxford University Press, Inc, 1979. Print.

Abrams, M.H. "A Glossary of Literary

Terms Seventh Edition". Cornel University: Earl McPeek, 1999. Print.

Baharudin, M."Esktensi `Tuhandalam

PandanganAtheism". Journal of IAIN

RadenIntan Lampung 6 (2012) : 215233. Print.

Balkin, J.M. "Deconstructive Practice and

Legal Theory".Yale Law School

LegalScholarship Repository 291

(1987): 1-48. Print.

Boland, B. J. "IntisariIman Kristen".

Jakarta: GunungMulia, 2000. Print.

Griffith K. "Writing Essay about

Literature". Greensboro: University of

North Carolina, 2011. Print.

Hakim, AdityaAkbar. "Dekonstruksi

KehidupanBeragamaDalam Novel Sang PencerahKaryaAkmalNaseryBasral ".

BAPALA1(2013): $4 \quad$.EJounalUNESA.Print.

Holman, H. C. "A Hand Book to Literature". Indiana Polis: Bobs Merrill Company, 1978. Print.

Liando, Nitha V. F. "Factors Affecting a

Successful Language

Learner".IndonesianJournal of

English Language Teaching 8 (2012): 22-50. Print.

Soedarmo, R." IkhtisarDogmatika “. Jakarta: GunungMulia, 2015. Print.

Verkuyl, J."AkuPercaya”. Jakarta: GunungMulia, 2001. Print.

Rice T. and Webber A. L. "Jesus Christ Superstar”. USA: Leeds Music Limited., 1970. Print.

Wuntu, C. N. "Connecting the Vanishing Flora, Fauna, and Its Relation to theIndianRemoval Policy as Seen in Cooper's the Leatherstocking Tales". Celt 15(2015): 97-117. Print. 